\title{
Invitro Antibacterial Screening of Extracts from Selected Ethiopian Medicinal
} Plants

\author{
Berhan Mengiste*, Yohannes Hagos, Fetene Moges, HabtamuTassew, G/hiwotTadesse, and \\ Awet Teklu \\ College of Veterinary Medicine, P.O.Box: 231, Mekelle University, Mekelle, Ethiopia \\ (*yasfaw2009@yahoo.com)
}

\begin{abstract}
Indigenous knowledge, literature reports and ethnobotanical records suggest that plants are the basis for medicines. They constitute natural source of antimicrobial drugs that will provide novel or lead compounds for the fight against disease. In this study, the antimicrobial activity of three selected Ethiopian medicinal plants was studied with the objective of screening their antibacterial activity. The fruits of Measalanceolata, aerial part of Cissus quadrangularis and leaf of Dodonae angustifolia were collected, air dried under shed, powdered and soaked in $80 \%$ methanol and extracted. In vitro antibacterial activity of the extracts was tested at different concentrations by using agar disc diffusion method and measuring the zone of inhibition. The plant extracts showed broad spectrum activity against gram positive ( $S$. aureus) as well as gram negative (E. coli) bacteria, except Cissus quadrangularis which did not show any activity against E. coli. Furthermore, the plant extracts had also concentration dependant zone of inhibition against the tested bacteria. In fact, the highest activity was obtained for Dodonae angustifolia at $1000 \mathrm{mg} / \mathrm{ml}$ against $S$. aureus. The activities are attributed to the presence of some secondary metabolites present in the tested plants which have been associated with antibacterial activities. This finding suggests that these medicinal plants can be potential source to isolate antibacterial drugs.
\end{abstract}

Keywords: Antibacterial activity, Disc diffusion, E. coli, Plant extract and S. aureus.

\section{INTRODUCTION}

Despite tremendous progress in veterinary medicine, infectious diseases caused by bacteria, fungi, viruses and parasites are still a major threat to human and animal health. The impact is particularly large in developing countries due to lack of availabilities of modern medicines and the emergence of widespread drug resistance (Alberto et al., 2009). The development of drug resistance as well as lack of availabilities of certain antibiotics has led to the search of new antimicrobial agents mainly among plant extracts with the goal to discover new chemical structures, which overcome the above disadvantages (Benharref et al., 2006). Current research on natural molecules and products primarily focuses on plants since they are locally available, less costly, and can be selected based on their ethno-medicinal uses (Arora and Kaur, 2007). Natural products perform various functions, and have interesting and useful biological activities (Adam 
et al., 1991). There are more than 35,000 plant species being used in various human cultures around the world for medicinal purpose (Jantan, 1998).

Maesalanceolatalocal name "kelewo", (family Myrsinaceae), is a tree or shrub that is used in traditional medicine against various diseases (Foubert et al., 2007). The fruit of this medicinal plant is widely used in East Africa to treat a variety of ailments, such as sore throat, tapeworms, hepatitis and cholera. In Central Africa, it is used against Entamoeba histolytica infections, while in Saudi Arabia a decoction of the heated fresh leaves is used to alleviate rheumatic arthritis. Maesalanceolata is also reported to have molluscicidal (Bagalwa and Chifundera, 2007), antifungal (Baisa et al., 2003), antischistosomal and anticestodal effects (Molgaard et al., 2001). Various rural communities in Ethiopia use this medicinal plant to treat human being as well as their livestock (Andreassen et al., 2001).

Cissus quadrangularis local name "YezhonAnjet"is a species belonging to the family Vitaceae (Sivarajan and Balachandran, 1984). It is found throughout the hotter parts of the world (Udupaet al., 1970). The stem of this medicinal plant is traditionally used for management of obesity as well as complications associated with metabolic disorders, alternative anthelmintic, dyspeptic, digestive, tonic, and analgesics in eye and ear diseases and also in the treatment of irregular menstruation (Julius et al., 2006).

Dodonae angustifolia local name "Kitkita/taheses (Sapindaceae)" is a small tree or shrub, commonly 2-8 m high, widely distributed throughout the tropics and subtropics (Friis, 1992). This plant hasa wide range of therapeutic applications including botanical pesticides (Ghosh and Ulaganathan, 2004), analgesic and antipyretic (Amabeoku et al., 2001), antiretroviral (Asrès et al., 2006) and antimalarial activities (Simonsen et al., 2001).

Studies conducted on different antimicrobial and phytochemical constituents of medicinal plants confirmed their use for treatment of microbial infections (both topical and systemic applications) as possible alternatives to modern drugs to which many infectious microorganisms have become resistant. Literature reports and ethnobotanical records suggest that plants are the basis for modern drugs in pharmaceutical industry. They constitute natural source of antimicrobial drugs that will provide novel or lead compounds that may be employed globally (Akinpelu and Onakoya, 2006). The objective of this study is therefore, to screen antibacterial activity of the claimed medicinal plants by measuring their zone of inhibition against the tested bacteria. 


\section{MATERIALS AND METHODS}

\subsection{Plant Material Collection and Extraction}

The test plants were collected from Mekelle and South Wollo, authenticated and a voucher specimen was deposited at Mekelle University, College of Veterinary Medicine. The test plants were, air-dried under shade and powdered by milling machine. The extraction method involved the separation of medicinally active portions of plant tissues as described by Ncube et al. (2008) by using $80 \%$ methanol as a solvent. The powdered plant material was macerated in $80 \%$ methanol for 72 hours and filtered using Wattman filter paper. After treating 3 times with $80 \%$ methanol, the filtrate was transferred into flask and allowed to evaporate by using rotary evaporator. Water from the extract was further evaporated on water bath and the yield was measured. The extracts were stored in a refrigerator at $4^{\circ} \mathrm{C}$ until use.

\subsection{Inoculum Preparation}

Two species of bacteria isolates, one gram positive (Staphylococcus aureus) and another gram negative (Escherichia coli) obtained from Microbiology Laboratory of National Veterinary Institute at Debre-zeit were used. The turbidity of actively growing bacterial suspension was adjusted to match the turbidity standard of $0.5 \mathrm{McFarland}$ units prepared by mixing $0.5 \mathrm{ml}$ of $1.75 \%$ (w/v) barium chloride dihydrate with $99.5 \mathrm{ml} \mathrm{1 \%} \mathrm{(v/v)} \mathrm{sulfuric} \mathrm{acid} \mathrm{(Willey} \mathrm{et} \mathrm{al.,} \mathrm{2008).}$ These actively growing bacteria were inoculated on Muller Hinton Agar.

\subsection{Antibacterial Bioassay}

Standard disc diffusion method described by Kirby-Bauer (Willey et al., 2008) was used for this study. Test discs were prepared by dipping and saturating sterilized filter paper discs in plant extracts. Same sized filter paper discs (6 mm diameter) absorbed the same volume of extract. For negative control discs impregnated by vehicle ( $80 \%$ methanol) were used while standard antibiotic discs (Cefoxitin) were used as positive control.The discs were applied on the cultured bacteria by sterile forceps approximately equidistance to each other.Finally the cultured bacteria were incubated for 24 hours at $37^{\circ} \mathrm{C}$. The diameter of zone of inhibition (mean of triplicates $\pm \mathrm{SD}$ ) as indicated by clear area which was devoid of growth of bacteria was measured.

\subsection{Experimental Design of the Study}

The test protocol is stated in Table 1. The crude extracts from each of the medicinal plants were tested at 1000, 500, and $250 \mathrm{mg} / \mathrm{ml}$. Cefoxitin was used as standard antibacterial drug (positive control) at $30 \mu \mathrm{g} / \mathrm{disc}$. Methanol was used as negative control. 
Table 1. Experimental design of the study

\begin{tabular}{|cll|}
\hline Group & \multicolumn{1}{c}{ Treatment } & Concentration $(\mathbf{m g} / \mathbf{m l})$ \\
\hline I & Crude extract & 250 \\
\hline II & Crude extract & 500 \\
\hline III & Crude extract & 1000 \\
\hline IV & +ve control (Cefoxitin) & $30 \mu \mathrm{g} / \mathrm{disc}$ \\
\hline V & -ve control (methanol) & $80 \%$ \\
\hline
\end{tabular}

\subsection{Data Analysis}

Data was entered in to Microsoft excel spread sheet and analyzed using SPSS version 15 software. The zone of inhibition was expressed as mean \pm SD. Statistical analysis was also undertaken by analysis of variance (one way ANOVA) coupled with Least Significant Difference (LSD) to compare result between plants and concentrations. Result was considered statistically significant at $\mathrm{P}$-value $<0.05$.

\section{RESULTS}

Initial screening of plants for possible antibacterial activity typically began by crude extracts obtained using $80 \%(\mathrm{v} / \mathrm{v})$ methanol in water. The extract yield ranges from 5-9\% on dried mass basis. The maximum yield was obtained from M.lancelata $(8.55 \%)$ and the minimum yield from D.angustifolia (5\%) (Table 2). The test plants showed positive activities as evidenced by a clear zone of inhibition against the tested bacteria. Though the response is not uniform, all plants showed activity against one or both bacterial strains used in this assay (Table 3 ).

The result indicated that all the three medicinal plants showed statistically significant $(\mathrm{p}<0.05)$ against S.aureus at all the tested concentrations but in a concentration-dependent manner (Table 4, Figures 1 and 2). All the test plants also showed statistically significant ( $<<0.05)$ against E.coli except C.quadrangularisthat did not show any activity against E.coli (Table 4, Figure 2). The highest zone of inhibition $(13.88 \mathrm{~mm})$ was obtained for D.angustifolia at $1000 \mathrm{mg} / \mathrm{ml}$ against S.aureus. This indicated that the tested medicinal plants have better antibacterial activity against S. aureus than E.coli (Table 4).

Table 2. Percentage yield of crude extracts from the test plants.

\begin{tabular}{|llll|}
\hline No & Test Plant & Parts Used & Yield (\%) \\
\hline 1 & Maesa lanceolata & Fruit & 8.55 \\
\hline 2 & Cissus quadrangularis & Aerial part & 5.74 \\
\hline 3 & Dodonae angustifolia & Leaves & 5.00 \\
\hline
\end{tabular}


Table 3. Summary of antibacterial activities of test plants against S. aureus and E. coli.

\begin{tabular}{|llc|}
\hline Plant & \multicolumn{2}{c|}{ Result (inhibition) } \\
\cline { 2 - 3 } & S. aureus & E. coli \\
\hline M. lanceolata & + & + \\
C. quadrangularis & + & - \\
D. angustifolia & + & + \\
Positive control & + & + \\
Negative control & - & - \\
\hline
\end{tabular}

Table 4. Antibacterial activity of the test plants against $S$. aureus and E. coli at different concentrations.

\begin{tabular}{|c|c|c|c|c|c|c|}
\hline \multirow[t]{2}{*}{ Test plant } & \multirow{2}{*}{$\begin{array}{l}\text { Conc. } \\
(\mathrm{mg} / \mathrm{ml})\end{array}$} & \multicolumn{4}{|c|}{ Zone of inhibition $(\mathrm{mm})($ mean $\pm s d)$} & \multirow{2}{*}{$\begin{array}{l}\text { Total p- } \\
\text { value }\end{array}$} \\
\hline & & S. aureus & p-value & E. coli & $p$-value & \\
\hline \multirow{3}{*}{ M. lanceolata } & 250 & $3.88 \pm 1.8$ & \multirow{3}{*}{$\mathrm{P}<0.05$} & $3.875 \pm 1.80$ & \multirow{3}{*}{$\mathrm{P}<0.05$} & $\mathrm{P}>0.05$ \\
\hline & 500 & $9.37 \pm 1.1$ & & $9.375 \pm 1.06$ & & $\mathrm{P}>0.05$ \\
\hline & 1000 & $10.00 \pm 1.95$ & & $9.625 \pm 1.30$ & & $\mathrm{P}>0.05$ \\
\hline \multirow[t]{3}{*}{ C. quadrangularis } & 250 & $8.25 \pm 1.16$ & \multirow{3}{*}{$\mathrm{P}<0.05$} & 0.000 & \multirow{3}{*}{$P>0.05$} & $\mathrm{P}<0.05$ \\
\hline & 500 & $11.13 \pm 1.55$ & & 0.000 & & $\mathrm{P}<0.05$ \\
\hline & 1000 & $11.875 \pm 1.46$ & & 0.000 & & $\mathrm{P}<0.05$ \\
\hline \multirow[t]{3}{*}{ D. angustofolia } & 250 & $6.78 \pm 2.78$ & \multirow{3}{*}{$\mathrm{P}<0.05$} & $3.875 \pm 1.80$ & \multirow{3}{*}{$\mathrm{P}<0.05$} & $\mathrm{P}<0.05$ \\
\hline & 500 & $12.25 \pm 1.80$ & & $10.0 \pm 1.06$ & & $\mathrm{P}<0.05$ \\
\hline & 1000 & $13.88 \pm 3.99$ & & $12.125 \pm 2.748$ & & $\mathrm{P}>0.05$ \\
\hline $\begin{array}{l}\text { Cefoxitin } \\
\text { (+ve control) }\end{array}$ & $30(\mu \mathrm{g})$ & $28.6 \pm 1.18$ & & $23.375 \pm 1.4078$ & & $\mathrm{P}<0.05$ \\
\hline $\begin{array}{l}\text { Methanol } \\
\text { (-ve control) }\end{array}$ & $80 \%$ & 0.00 & & 0.00 & & $\mathrm{P}>0.05$ \\
\hline
\end{tabular}

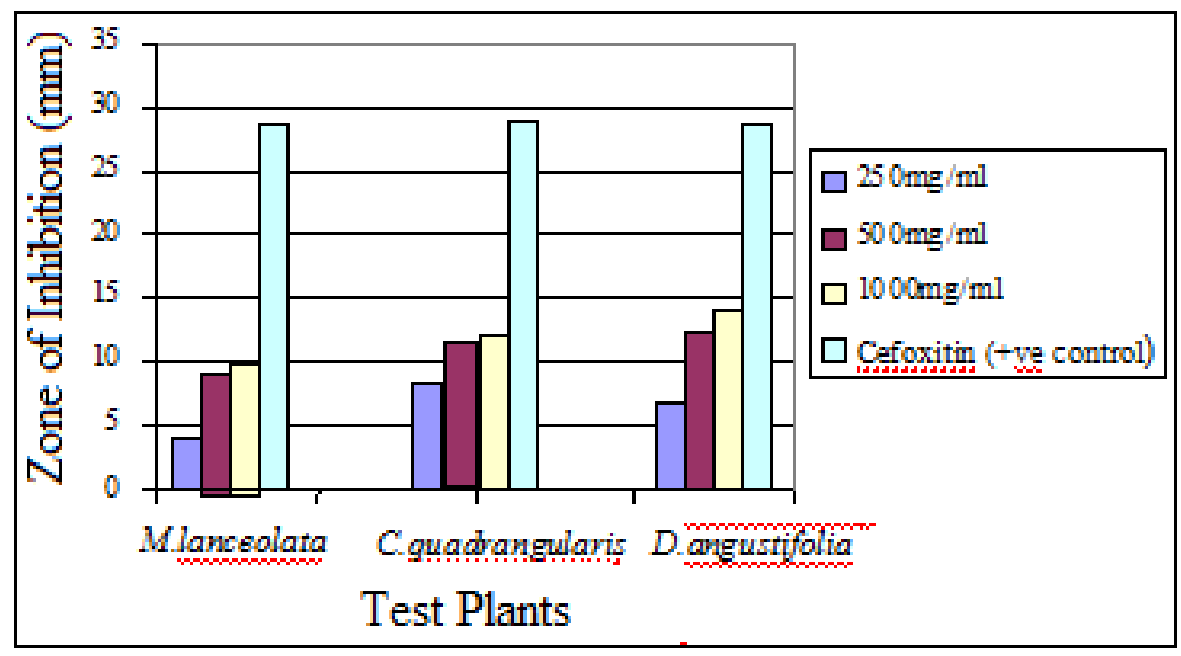

Figure 1.Inhibition of $S$. aureus by extracts of the test plants at different concentrations. 


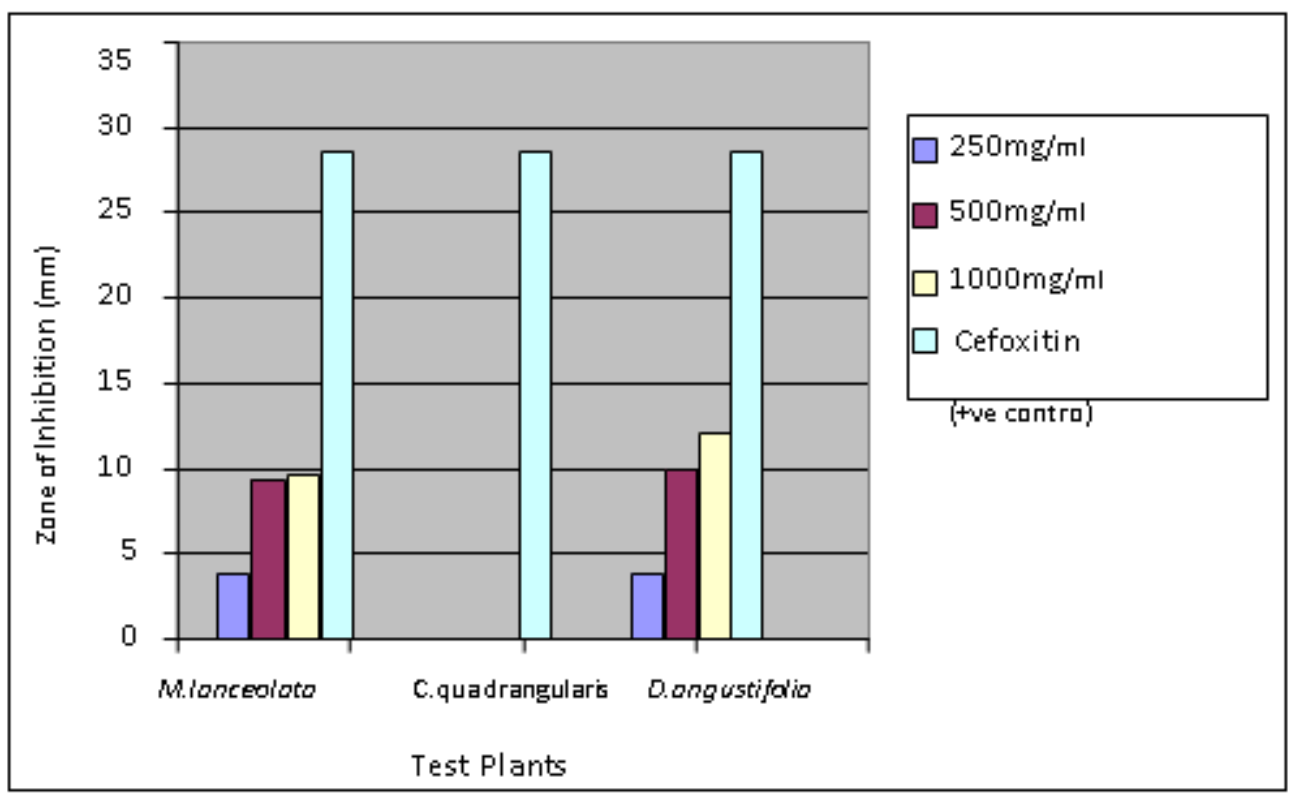

Figure 2.Inhibition of $E$. coli by extracts of the test plants at different concentrations.

\section{DISCUSSION}

The result of this study showed that Measa lanceolata, Cissus quadrangularis and Dodonae angustifolia extracts showed varied antibacterial activity against the tested organisms, except for Cissus quadrangularis that showed no activity against E.coli (Table 3). This result suggests that the extracts of these plants are broad spectrum in their activities. This correlates with the observation of previous researches that the plants used have effect of antimicrobial activity (Jebamalai et al., 2010).

In this study the result clearly showed the contrary to the report of Samuel (2004) who reported that M.lanceolata did not have activity against E.coli. This might be due to the variation in the plant part used; where in this study fruit of the plant was used instead of leaves unlike that of the previous study.

Similarly, the present study is in line with the findings of Kashikar and George (2006) who reported that C.quadrangularis has antibacterial activity against S.aureus and found ineffective against E.coli. This antibacterial activity of C.quadrangularis is a result of the presence of phytochemical constituents that are alkaloids, flavonoids, saponins, steroids, tannins and aminoacids studied by Anitha et al. (2006). 
According to Saxena et al.; (2003), D.angustifolia has several classes of secondary metabolites which are responsible for antibacterial activity, but the most important and diverse biopotency has been observed in alkaloids, quassinoids and sesquiterpene lactones.According to Alexandru et al. (2007), the crude extract of D.angustifolia has antibacterial activity against both S.aureus and E.coli. However, in this study the result clearly showed thatthis plant is effective against E.coli. The possible explanation for this difference in activity might be ecological difference on their distribution where the plants were collected that varied the concentration of the active ingredients.

\section{CONCLUSION}

The test plants showed antibacterial activity as evidenced by high zone of inhibition. This finding suggests that there is possibility to isolate potential antibacterial drugs from these medicinal plants. The finding of this study also hints that potential lead molecule can be isolated from these medicinal plants that can be a base for synthesis of effective antibacterial drugs. Phytochemical screening of the tested plants have to be done to detect secondary metabolites that are responsible for their antibacterial activity and also toxicity tests and in vivo experiments of these plants is required to assure safety and effectiveness.Generally, further studies on fractions and isolates of the plants for antibacterial activity should be conducted.

\section{ACKNOWLEDGEMENTS}

The authors of this paper like to acknowledge NORAD project of Mekelle University for provision of financial support to conduct this study. The authors also extend great appreciation to the Department of Pharmacy, Mekelle University, for their technical support and provision of facility. The authors also like to acknowledge Mr. Tsegaye Tikue, Mr. Natnael Tessema, and Mr. Seid for their valuable technical support in the laboratory works.

\section{REFERENCE}

Adam, D., Galal, M., Bashir, M \& Salih, D. 1991. Activity of water extracts of Albiziaanthelmintica and Alebbek Backs against experimental Hymenolepisdiminuta infection in rats. J. Ethnopharmacol.,31: 333-337. 
Akinpelu, D.A \& Onakoya, T.M.2006. Antimicrobial activity of medicinal plants used in folklore remedies in south-western Nigeria. African J.Biotechnol.,5 (11): 1078-1081.

Alberto, R., Zampini, C., Cuello, S., Ordonez, M., Almeida, D., Solorzano, E \& Isla, I. 2009. Antimicrobial activity of selected plant species from the Argentine punaagainst sensitive and multi resistant bacteria. J. Ethnopharmacol.,124: 499-505.

Alexandru, V., Balan, M., Gaspar, A \& Coroiu, V. 2007. Antioxidant activity, phenolics and flavonoid contents of some selected Romanian medicinal plants. Planta Med., 73:797901.

Amabeoku, G., Eagles, P., Scott, G., Spring field, E \& Mayeng, I.2001. Analgesic and antipyretic effect of Dodonaeangustifolia and Salvia africalutea. J.Ethnopharmacol.,75: 115-126.

Andreassen, J., Molgaard, P., Nielsen, B., Rasmussen, E., Drummond, R \& Makaza, N. 2001.Anthelmintic screening of Zimbabwean plants traditionally used against schistosomiasis.J.Ethnopharmacol,74(3): 257-264.

Anitha, J. R., Akila, S., Velliyur, K. G \& Sudarsanam, D. 2010. Antimicrobial profile of Cissusquardangularis.J. Herbal Med and Toxicol.,4(2): 177-180.

Arora S \& Kaur, J. 2007. Antibacterial activity of some Indian medicinal plants. J. Nat Med.,61: 313-317.

Asres, K., Bucar, F \& Gbbons, S. 2006. Radical scavenging compounds from Ethiopian medicinal plants. J.Ethnopharmacol.,24: 23-35.

Bagalwa, M \& Chifundera K. 2007. Environmental impact evaluation of the stem bark extract of Maesalanceolata used in Democratic Republic of Congo.J.Ethnopharmacol.,55: 12-22.

Baisa, P., Okemob, O \& Vivancoa, M. 2003.In vitro activities of Maesalanceolataextracts against fungal plant pathogens.J. Fitoter., 74: 312-316.

Benharref, A., Bouamama, H., Noel, T., Villard, J \& Jana, M. 2006. Antimicrobial activities of the leaf extract of two Moroccan CistusL species. J.Ethnopharmacol.,104:104-107.

Foubert, K., Gonzalez-Guzman, M., Goossens, A., Theunis, M., Pollier, J., Vlietinck, J., Pieters, C \& Apers, S. 2007. Determination of saponins in Maesalanceolataby LC-UV: Development and validation.J.Phytochem., 17-30.

Friis, I. 1992. Forests and forest trees of north-east tropical Africa. Kew.Bull. Add. Sr., 15: 1-39. 
Ghosh, M \& Ulaganathan, K. 2004.Dodonaeangustifolia. A potential biopesticide against Helicoverpaarmigera. Current Science, 86: 26-28.

Jantan, I. 1998. Conservation of medicinal plants and their traditional knowledge. Proceedings of the Seminar, University Putra, Malaysia, pp.20-24

Jebamalai, A.R., Selvaraj, A., V. G., Kanniappan, V. G \&Dorairaj, S. 2010. Antimicrobial profile of Cissusquadrangularis.J. Herbal Med and Toxicol.,4(2): 177-180.

Julius, O., Dieudonne, K., Gabriel, A., Claudia, M \&Xavio, T. 2006. The use of Cissusquadrangularisformulation in the management of weight loss and metabolic syndrome.Lipids in Health and Disease, 5: 24-33.

Kashikar, P \& George, I. 2006. Antibacterial Activity of Cissusquadrangularis. Indian J. Pharm Sci.,68(2): 245-247.

Molgaard, P., Nielsen, S.B., Rasmussen, D.E., Drummond, B.R., Makaza, N \&Andreassen, J.2001.Anthelmintic screening of Zimbabwean plants traditionally used against schistosomiasis.J.Ethnopharmacol.,74(3):257-264.

Ncube, N.S., Afolayan, A.J\&Okoh, A.I.2008. Assessment techniques of antimicrobial properties of natural compounds of plant origin: current methods and future trends. African J.Biotechnol.,7(12): 1797-1806.

Samuel, T. 2004. Screening for antimicrobial and anti-inflammatory activity and formulation studies on the extracts of selected medicinal plants. MSc thesis, Addis Ababa University, 121 (unpubl).

Saxena, S., Pant, N., Jain, D \&Bhakuni, R. 2003. Antimalarial agents from plant sources. CurrentScience, 85:13-39.

Simonsen, H., Braendegaard, J., Ulla, N.,Smitt, W., Nyman, U., Palpu, U \&Joshi, J. 2001. Invitro screening of Indian medicinal plants for antiplasmodial activities. J.Ethnopharmacol.,74:195-204.

Sivarajan, V \& Balachandran, I. 1984.Ayurvedic Drugs and their plant sources.Oxford and India Book PA, New Delhi, pp.496-497.

Udupa, N., Chaturvedi, N \& Tripathi, N. 1970. Advances in research in Indian Medicine. J. Science, 12:165-96.

Willey, J.M., Scherwood, L.M \& Woolverton, C.J. 2008. Text Book of Microbiology. $7^{\text {th }}$ ed, Mcgrow-Hill, Newyork, pp.840-882. 